Ristić, I., Popović, D., \& Milovanović, B. (2021). Indicators of the wider social context and academic performance of the deaf and hard of hearing students, International Journal of Cognitive Research in Science, Engineering and Education (IJCRSEE), 9(2), 265-274.

\title{
Indicators of the Wider Social Context and Academic Performance of the Deaf and Hard of Hearing Students
}

\author{
Ivana Ristićc ${ }^{*}$ (D), Daliborka Popović (iD), Boško Milovanović3 (iD \\ ${ }^{1}$ University of Priština in Kosovska Mitrovica, Teacher Education Faculty, Serbia, e-mail: ivana.ristic@pr.ac.rs \\ 2University of Priština in Kosovska Mitrovica, Teacher Education Faculty, Serbia, e-mail: daliborka.popovic@pr.ac.rs \\ 3University of Priština in Kosovska Mitrovica, Teacher Education Faculty, Serbia, e-mail: bosko.milovanovic@pr.ac.rs
}

\begin{abstract}
The evaluation of the educational system is performed through the prism of the relationship between the individual person and society, taking into account social and economic, political, cultural, socio-economic, family tendencies and directions of development. Therefore, the analysis of the influence of social, economic, welfare, psychological and school factors is necessary in order to identify the positive, but also the negative influences of the factors and thus prevents the poor academic results of the deaf and hard of hearing students. The research problem is aimed at a wider understanding of the factors of academic achievement or failure of the deaf and hard of hearing students in order to improve the quality of their education and upbringing of deaf and hard of hearing students in schools for the deaf and hard of hearing, but also in the field of inclusive education. This paper presents a part of the research results related to the correlation between the indicators of the wider social context and the academic performance of the deaf and hard hearing students. The sample consisted of 59 respondents attending schools for the deaf and hard of hearing students in the Republic of Serbia. For this research, the method of theoretical analysis and synthesis was used in the study of the relevant literature and the determination of theoretical facts important for the research problem, and the survey and content analysis were used as the research techniques. The results showed that there were no statistically significant differences in academic achievement in relation to the type of environment in which the students are living, or in relation to the presence of the cultural institutions in the environment. There is a difference in the academic achievements of the deaf and hard of hearing students in whose environment there are or there are no active organizations for the deaf and hard of hearing, which represents important data in order to create strategies to support the deaf and hard of hearing students.
\end{abstract}

Keywords: deaf and hard of hearing students, academic performance, indicators of a wider social context.

\section{Introduction}

At the end of the first half of the last century, the focus of researchers was on examining the influence of factors of a wider social context on students' academic performance (Poulou, 2014). The research results have shown that the achievement of students is significantly affected by cultural and environmental differences as well as social class. Various aspects point to the correlation of middle and working classes with varying performance in education. Poverty, population density and social class, in addition to causing poor results, significantly deny and inhibit further progress in education (Roksandić, 2016). Also, research findings have shown that poverty lowers the level of education of family members, and parental expectations of children. Furthermore, less educated and poor parents have less money, energy and time to devote to encourage the development of the full potential of their children. Studies have established that the poverty of one generation affects the life chances of the following, regardless of the ability of the following generation (Arroyo, Rhoad and Drew, 1999; Hill and Taylor, 2004; Seely, 2004). Then, unequal division of possibilities per social class affect their attitude towards education, so children from economically deprived families often have more pronounced negative attitudes towards school, less support to succeed in school and lower motivation for achievement (Howse, 2010). Ivanovic (2008) agrues that social background also significantly contributes the formation of attitude on professional orientation.

The academic performance of an individual is also conditioned by the existing cultural differences. Namely, one of the important indicators of academic achievement is the culturally deprived environment, 
Ristić, I., Popović, D., \& Milovanović, B. (2021). Indicators of the wider social context and academic performance of the deaf and hard of hearing students, International Journal of Cognitive Research in Science, Engineering and Education (IJCRSEE), 9(2), 265-274.

and each family accepts the cultural values of the environment to which it belongs (West and Pennell, 2003). In addition, certain cultural characteristics are common to almost every family, while on the other hand, there are several specific cultural characteristics for each subculture, which are reflected in academic achievement (Cook and Tseng, 2019).

As a factor of wider social context, it is possible to observe the difference between urban and rural areas either according to their structural characteristics and composition of the social institutions in them or according to the attitude of these areas towards education. While in urban areas there is a jagged network of different institutions and complex influences on the behaviour and relationships of people, there is a more complex structure of family life in rural areas, a simpler arrangement of social institutions. Urban and rural areas differ in the moral values, educational level of the population, the general level of the culture, economic elements which significantly affect the formation and development of certain types and patterns of behaviour, but also the good or poor academic achievement (Jevtić, 2014). Findings of the researchers in the world have shown that children from neighbourhoods inhabited by people without qualifications often do not graduate from school and children from isolated rural settlements after basic education face difficulties in furthering education (Blanchett, Mumford and Beachum, 2005).

Research conducted in our country shows that with a higher degree of urban environment achievements of students are greater (Malinić, 2009). On the other hand, the results of some researches indicate that the success of students is significantly influenced by the educational level of parents than the type of environment in which they live (Havelka, 2000; Jurčević Lozančić and Kunert, 2015).

The process of socialization and education is stimulated or slowed down by educational incentives determined by the family climate and cultural elements. Thus, under the influence of cultural and family factors, children begin their education with different prior knowledge and different degrees of maturity for education. Research findings show that there are specially marked differences in the performance of children from urban and rural areas, where much better success is of children living in cities (Ivanovic, 2008). Every family accepts the cultural values of the environment to which it belongs, and one of the important indicators of academic achievement is the culturally deprived environment.

Considerations of the influence of the social environment on the academic achievement of students are possible from the aspect of existing cultural differences and social classes. Researches in the field of sociology of education direct their attention to the question of the impact of socio-economic status and education of parents on growing up, socialization, and education for children. It is not uncommon to ask why members of individual social groups achieve a higher level of success in schooling than other groups (Jurčević Lozančić and Kunert, 2015). The results of the research show that school success grows from the bottom to the top of the class system, and social inequalities between classes are explained by different degrees of the presence of achievement syndrome. The characteristic of the lower classes is that the achievement motive is not part of their aspirations and mentality. By contrast, members of the middle and high class have developed motivation for social success, which is transmitted to their children and in such a manner affects better academic achievement. Researches that have addressed the impact of social origin on education indicate that there is a connection between class origin and success at school (Ivanovic, 2008).

Good academic achievements hava a significant impact on the development of the child's personality and its overall functioning and it is a problem not only for individuals, teachers, students and parents but also for society as a whole. The interest of students, families, schools and the wider social environment to see all the causes that lead to failure and create conditions for optimal development and achievement of students have root in the fact that the consequences of poor academic performance affect the quality of life of the individual as a whole.

Family, school and social environment stand out among the factors of the external environment as those factors that have the strongest influence on the academic performance of students. A great number of research works point out the socio-economic and socio-cultural stimulating aspect of the family and are characterized by the degree of relevance which is attributed to a group of factors (Pavkovic, Roksandić and Kovacevic, 2018). On one hand, the authors emphasize the child's academic performance is predominantly determined by family relationships and patterns of behaviour within the family (Redding and Walberg, 2012; Petersen, 2010), while on the other hand, research findings highlight the impact of socio-economic status on academic performance (Leinonen, Solantaus and Punamaki, 2003; Swift, 1975; Taylor, Roberts and Jacobson, 1997). The education level of parents, family income and parental occupations are considered as the most reliable indicator of socio-economic status (Simić-Vukomanović, Đukić Dejanović, Đonović and Borovćanin, 2012). Results of research regarding the correlation of the conditions of family environment and academic achievement show that there is a significant correlation between father's educational level and success in school, as well as income and housing conditions 
Ristić, I., Popović, D., \& Milovanović, B. (2021). Indicators of the wider social context and academic performance of the deaf and hard of hearing students, International Journal of Cognitive Research in Science, Engineering and Education (IJCRSEE), $9(2), 265-274$.

(Stanojlović, 2012). The influence of these factors is combined through continuous interaction, so wider socio-economic factors are reflected indirectly on the socio-economic and socio-cultural status of the family and through parents affect the child's school achievement (Fantuzzo, Tighe and Childs, 2000; Grolnick and Slowiaczek, 1994; Grolnick et al., 1997).

The family as the basic social environment in which the child's personality is formed and the school as an institutional form of education build a system that operationalizes its activity by the interaction of parents and teachers (Riley and Ungerleider, 2012; Roksandić and Kovačević, 2016a; Popović, 2019; Stamatović and Stojanović, 2019). One of the key factors in alignment and achieving common objectives is including parents in school activities and decision-making (Sheridan and Kratochwill, 2007; Roksandić, 2016). Conditions for the achievement of the basic tasks of education and training process, acquisition of knowledge, skills and habits in line with the potential of each child individually is created by building a relationship of mutual respect and trust (Guardino and Antia, 2012; Roksandić, 2016; Ristić, 2018; Roksandić, Pavković and Kovačević, 2018). What is more, the school environment promotes and enhances the competence of parents for the upbringing and realization of high-quality family relationships (Epstein, 2010; Epstein et al, 2018; Zins et al., 2004; Roksandić and Kovačević, 2016a; Popović, 2019).

Looking at the wider picture, at the societal level, in addition to the above, several factors of the social environment which include requirements, organization, or processes in which the social life is carried out, participate in the process of education and upbringing. Between social environment and school, there is continuous interaction, correlation and interdependence. On one hand, the environment provides inputs to the system of education, expresses requirements and expectations, and on the other hand, it appears as an integral, direct and parallel carrier of educational impact.

Research results showed that an unsupportive and inadequate school environment creates the risk of poor academic performance of students, poor grades and dropout (Chen, Chang and He, 2008; Mijatović and Radovanović, 2020; Seeley, 2004). Schools differ regarding the conditions they provide, and the progress of students is different in different schools. The elements that determine the success or failure of the school are from the group of material and technical conditions, quality of teaching and staff structure as well as the attraction of the curriculum and extracurricular activities (Malinić, 2014; Malinić, 2009; Vilotijević and Vilotijević 2014).

The group of authors states that the poor academic achievement of students arises from the internal organization of schoolwork and the organization of the teaching process. We believe that the school today is very challenged because of the "race" with the media. If the school accepts that one of the basic tasks is to provide "necessary information" to students, then it agrees in advance to a supporting role, and to defeat (Milovanović, 2014).

Empirical findings confirmed that the traditional teaching and frontal forms of work is one of the most common causes of poor academic performance which misses group, cooperative work and that students are rarely encouraged to talk and discuss things (llić-Stošović 2006; Kovačević, 2007; Roksandić, 2014). Although, the teacher and his role in the teaching process indisputably contribute to academic achievement, especially the teacher's expectations of students and their behaviour (Arroy, Rhoad and Drew, 1999; Stanojević and Jovanović, 2018). By the attitude, relationship and skills, the teacher is the one who creates a stimulating atmosphere and the learning situation that will enable versatile development of each student (Jakšić and Malinić, 2019).

Research of academic achievement in the population of deaf and hard of hearing students in our country included the variables, such as sign language, technics of reading and level of understanding of reading, competencies of teacher of information and communication technology, teaching strategies and application of individual education plans, independent writing (Bigler et al., 2019; Boerrigter et al., 2019; Radoman and Nikolić, 2013; Karić et al., 2012; Dimić and Kljaić, 2011; Radovanović and Karić 2011). The increase in the number of both theoretical and empirical kinds of research on academic achievements over the past decades speaks of the relevance of this problem and indicates its complexity.

\section{Materials and Methods}

\section{Research goal}

Following the findings of previous researches on academic achievement confirming the several factors correlation in the impact on academic achievement, initial expectations in this research were directed towards the potential of confirming the correlation when it comes to the academic performance of deaf and hard of hearing students. With the deaf and hard of hearing students the reciprocal impact of various indicators in conjunction with a consequence of primary impairment, the issue of academic 
achievement seems particularly complex. Seen through the prism of the consequences of hearing impairment, the influence of these factors does not always result in positive educational outcomes, so the research problem was focused on a wider understanding of the factors of academic performance of deaf and hard of hearing students.

The research aimed to examine external indicators of academic performance of deaf and hard of hearing students, viewed through indicators of a wider social context.

\section{Research hypotheses}

The basic hypothesis is defined as there is a statistically significant correlation between external, indicators of the wider social context and academic performance of the deaf and hard of hearing students.

Specific research hypotheses are defined as assumptions that:

- there is a statistically significant correlation between the type of environment and academic performance,

- there is a statistically significant correlation between the existence of cultural institutions in the place of education and academic performance,

- there is a statistically significant correlation between the existence of organizations for the deaf and hard of hearing in the place of residence and academic performance.

\section{Sample for the research}

The research sample included 59 respondents who attend a school for the deaf and hard of hearing students in the territory of the Republic of Serbia. Regarding academic performance, 28 respondents were excellent students $(47.5 \%), 13$ respondents were very good students $(22.0 \%), 14$ respondents were good students (23.7\%) and 4 respondents were close fail students (6.8\%). Regarding the hearing impairment, there were 35 deaf respondents $(59.3 \%)$ and 24 hard of hearing respondents $(40.7 \%)$. In relation to the place of residence, there were $19(32.7 \%)$ respondents from the rural area (with population up to 10,000), $24(41.3 \%$ ) respondents who live in small town (with a population up to 100,000) and 15 respondents $(25,8 \%$ ) with a place of residence in the city (with a population over 100,000). In relation to the presence of cultural institutions in the place of residence there were $32(54.2 \%)$ respondents in whose environment there are cultural institutions, 20 respondents (33.9\%) in whose environment there are no cultural institutions, $11.9 \%$ of respondents did not reply to this question. In relation to the existence of deaf and hard of hearing organizations in the place of residence, there were 18 respondents $(30.5 \%)$ in whose place of residence there are active organizations for deaf and hard of hearing persons, while in the environment where 41 respondents live $(69.5 \%)$ there are no organizations for the deaf and hard of hearing.

\section{Methods, techniques and instruments}

For the research, the methods of theoretical analysis and synthesis were used to study relevant literature and determine the theoretical facts relevant to the research problem. Relating the research techniques, survey and analysis of the contents were used. In addition to general information about the respondent, the questionnaire contained a list of questions about the place of residence, the presence of cultural institutions in the place of residence, the existence of organizations for deaf and hard of hearing in the place of residence.

\section{Statistical data processing}

Data on socio-economic indicators of academic performance of the deaf and hard of hearing students were processed using software for statistical data processing SPSS 20.0. Descriptive statistics frequencies, percentages, arithmetic averages and standard deviations - were used to present the results. Spearman's (nonparametric) and Pearson's (linear) correlation coefficient were used to establish the relationship between variables. The T-test for independent samples was used to determine the significance of differences in academic performance between students in whose environment there are or there are no cultural institutions, among students in whose environment there are or there are no organizations for the deaf and hard of hearing. In the listed cases, the children were divided into two groups. The analysis of variance for independent samples examined the significance of differences in the academic performance of students from different backgrounds. 
Ristić, I., Popović, D., \& Milovanović, B. (2021). Indicators of the wider social context and academic performance of the deaf and hard of hearing students, International Journal of Cognitive Research in Science, Engineering and Education (IJCRSEE), 9(2), 265-274.

\section{Results}

Results obtained in the research are presented compared to defined variables.

1.Type of environment and academic achievement of the deaf and hard of hearing students

Table 1

Difference between the respondents from different backgrounds in relation to academic performance

\begin{tabular}{cccccc}
\hline $\begin{array}{c}\text { Place of } \\
\text { residence }\end{array}$ & $\mathrm{N}$ & AS & Sd & $\mathrm{F}$ & $\mathrm{p}$ \\
\hline City & 15 & 4.08 & .84 & .140 & .870 \\
\hline Town & 24 & 3.92 & 1.05 & & \\
\hline Village & 19 & 4.02 & .96 & & \\
\hline$p<.05^{\star} ; p<.01^{\star \star} ; p<.001^{\star \star *}$ & & &
\end{tabular}

The results of the research related to the academic performance of the deaf and hard of hearing students according to the place of residence showed that in the city there were $43.8 \%$ of excellent students and an equal number of very good students, and good and close fail students $12.5 \%$. The largest number of excellent students was in the town $45.8 \%$ and the village $52.6 \%$. In the town, there were $25.0 \%$ of very good and $20.8 \%$ of good students, while in the village there were $10.5 \%$ of very good and $21.1 \%$ of good students. About the place of residence, in all three observed groups, there were the fewest students who achieved very poor academic results.

The obtained results (Table 1) showed that the F- quotient is not statistically significant, ie. that there are no statistically significant differences in academic performance between students from the city, town and students from rural areas $(p=0.870)$.

2. Results of the correlation between the existence of cultural institutions in the environment and academic performance

Table 2

Results of examining the significance of differences in children's academic performance in connection to the existence of cultural institutions in the environment in which they live

\begin{tabular}{lrrrl}
\hline Cultural & $\mathrm{M}$ & $\mathrm{Sd}$ & $\mathrm{t}$ & $\mathrm{P}$ \\
institutions & \multicolumn{1}{c}{$\mathrm{T}$} & 1.03 & 1.162 & .251 \\
Present & 4.10 & .84 & & \\
Not Present & 3.78 & & & \\
\hline
\end{tabular}

$p<.05^{*} ; p<.01^{* \star} ; p<.001^{* \pi *}$

The results of research related to the distribution of students according to academic performance about the existence of cultural institutions in the place of residence show that in places with cultural institutions, there are $50.0 \%$ of the excellent students, while there are $15.6 \%$ of very good students, $12.5 \%$ good students and $9.4 \%$ close fail students. In places where there are no cultural institutions, there are $40 \%$ of excellent students, but fewer students with close fail grades. $20.0 \%$ are good students in places where there are no cultural institutions, while $25 \%$ of students have academic success. The situation regarding the presence of cultural institutions shows that the most common institution was the theatre $(40.6 \%)$, followed by museums $(28.1 \%)$. The art galleries were present the least $(3.1 \%)$. By crossreferencing the data on the presence and type of cultural institutions in the place of residence and academic performance of the deaf and hard of hearing students obtained results showed that there was no statistically significant difference in academic performance between children in whose environment there are and in whose environment there are no cultural institutions (Table 2). 
Ristić, I., Popović, D., \& Milovanović, B. (2021). Indicators of the wider social context and academic performance of the deaf and hard of hearing students, International Journal of Cognitive Research in Science, Engineering and Education (IJCRSEE), $9(2), 265-274$.

\section{Organizations for the deaf and hard of hearing in the place of residence and academic performance}

\section{Table 3}

Results of the t-test for examining the significance of differences in children's academic performance in relation to the existence of active organizations for the deaf and hard of hearing in the environment in which they live

\begin{tabular}{lcccc}
\hline $\begin{array}{l}\text { Active organizations for the deaf and hard of } \\
\text { hearing }\end{array}$ & AS & Sd & T & P \\
\cline { 2 - 5 } \begin{tabular}{l} 
Present \\
\cline { 2 - 4 }
\end{tabular} & 4.41 & .74 & 2.613 & $\mathbf{. 0 1 2}^{\text {* }}$ \\
\hline Not present & 3.80 & .98 & & \\
\hline
\end{tabular}

$p<.05^{\star} ; p<.01^{\star \star \pi} ; p<.001^{\star \star \star *}$

Analysis of the results of research relating to the distribution of students according to academic achievement in relation to the presence of the organizations for the deaf and hard of hearing showed that there are $66.7 \%$ of excellent students in the place where there are organizations for the deaf and hard of hearing, very good students $16.6 \%$, while there is an equal number of $5.6 \%$ of good and close fail students. Regarding academic performance in the areas in which respondents have declared that there is no organization for the deaf and hard of hearing, there are $39.0 \%$ of excellent students, $17.1 \%$ of very good, $24.4 \%$ of good, while close fail were $7.3 \%$ of students.

In relation to the type of active organization for the deaf and hard of hearing $61.8 \%$ of respondents cited there is the Association of the Deaf and Hard of Hearing in their place of residence, $22.2 \%$ that there is the Federation of the Deaf and Hard of Hearing, and 1 respondent cited the existence of creative workshops, metropolitan Association to help people with disabilities and daycare for people with special needs.

Cross-referencing of data about the organization for the deaf and hard of hearing in the place of residence and academic achievement (Table 3 ), the results of the t-test for examination of the significance of differences in performance at school of the deaf and hard of hearing students regarding the presence of active organizations for the deaf and hard of hearing in the environment in which they live showed that there are statistically significant differences in academic performance of students in relation to the presence of active organizations for the deaf and hard of hearing in the place where students live $(p=$ 0.012).

\section{Discussions}

The attention of researchers has focused on the impact factor of the wider social context on the academic performance of students just before the end of the last century. Important evidence of the impact of cultural, environmental, class differences on academic performance are the results of previous studies on the correlation between wider social context and academic performance (Malinić, 2009). It is pointed out that the key cause of academic failure is deprivation caused by inadequate social and emotional development (Morison-Gutman, Sameroff and Cole, 2003).

Rural and urban areas also differ according to the general level of culture, educational level of the population, moral values, economic elements, which significantly affect the construction of certain forms and patterns of behaviour, as well as achievement and underachievement at school (Karchmer and Mitchell, 2003). The results of foreign research show that children from neighbourhoods where the population lives without qualifications usually do not graduate from school, that children from isolated rural settlements after primary education encounter difficulties in continuing their education (Harvey and Kentish, 2010). Research carried out in our country shows that the success of the students in more urban areas is better, while the number of students with underachievement increases in the poorer areas, that is why students from Belgrade schools show better academic performance on a test of knowledge than students from other, smaller cities, suburban and rural areas (The first research problem of this research was to examine the difference in the academic achievement of the deaf and hard of hearing students regarding the type of environment in which students live. The significance of the correlation between respondents from different backgrounds about academic achievement was checked by analysis of variance of non-repeated measures (Table 1). The analysis of the obtained results showed that there 
Ristić, I., Popović, D., \& Milovanović, B. (2021). Indicators of the wider social context and academic performance of the deaf and hard of hearing students, International Journal of Cognitive Research in Science, Engineering and Education (IJCRSEE), $9(2), 265-274$.

was no statistically significant difference in performance at school between pupils from cities, towns, and rural students $(p=0.870)$. One possible explanation of the results obtained is given in terms of there is a significant number of students included in the sample who use boarding school accommodation. Thus, taking into account the time that students spend in school and boarding school about the time they spend in their place of residence (in the real environment), we can evaluate the obtained result as expected. Besides that in the modern age, demographic, social and economic social changes have led to mitigating the differences between rural and urban areas that had previously existed (Kamal and Bener, 2009). Today's availability of modern information technologies, the use of the Internet provides access to various content and information for both urban and rural residents. The findings of this study are consistent with the results of some similar studies in our country which show that student's achievement is significantly affected by the educational level of parents rather than the type of environment in which the students live (Klarin, 2006).

Another research problem was focused on understanding the correlation between the existence of cultural institutions in the environment and academic performance. Previous research has shown that cultural and environmental differences, as well as social class significantly affect student achievement, and this research looked at possible differences in the academic performance of the deaf and hard of hearing students regarding some potentials of the social environment in which they live. The existence of a difference in the academic achievement of the deaf and hard of hearing students regarding the potentials of the social environment in which they live was examined by a t-test for independent samples. The results showed that there were no statistically significant differences in academic performance between children in whose environment there are and in whose environment there are cultural institutions present (Table 2).

The third research problem was to examine whether the presence of the deaf and hard of hearing organizations in the place of residence of the deaf and hard of hearing students correlates with the academic performance of the deaf. Analysis of the obtained results of the t-test shows that there are differences in performance at school between students in the environment where there are or there are no active organizations for the deaf and hard of hearing present, these two groups (Table 3). The results confirm the role played by organizations for the deaf and hard of hearing in the functioning of the everyday life of the deaf and hard of hearing students and their family. These are places where families can find support, get directions to educate their children, and for children later in life, a place of cultural and social development. The significance of the obtained results is certainly in considering the possibilities for improving and strengthening the functioning and cooperation of deaf and hard of hearing organizations with schools and families of deaf and hard of hearing students to improve and prevent poor academic results. Furthermore, the existence of organization for the deaf and hard of hearing contribute both cultural and pedagogical level of environment and family, which does not only affect academic achievement, as well as their abilities but also the cultural and social deprivation prevents students to fully develop and use their abilities, intellectual as well as social (Reed, Shirin and Kreimeye 2008; Roksandić and Kovačević, 2016b).

Based on the previous analysis, the results of research and discussions, the analysis of formulated hypothesis for this study shows that the initial assumption of the correlation between the indicators of the wider social context and academic achievement of the deaf and hard of hearing students are partially confirmed, and partly discarded.

\section{Conclusions}

The structure of factors in a wider social environment, as well as their quality, is reflected in the functioning of the family, its cultural values and behaviour patterns, but also in the functioning of the society as a whole, and it is necessary to review in their correlation all aspects of the functioning. Thus, achieving success in school is conditioned by a large number of factors that can have a positive, stimulating, but also a negative, inhibitory effect. On one hand, there are the intellectual abilities of the child, and on the other hand, everyday life with the family and the influence of the family and the culture in which it belongs. Based on a review of the literature and an analysis of several realized types of research of school achievement of deaf and hard of hearing students, the results of this research are somewhat expected.

The results showed that as a specific indicator of academic performance in a group of factors of wider social context distinguished by the presence of the organizations for the deaf and hard of hearing students. The existence of such institutions is extremely important for the families of the deaf and hard of hearing students. These are places where they have the opportunity to meet other families, exchange experiences, get help in situations when they need it, resolve dilemmas, dissipate prejudices. For the deaf 
Ristić, I., Popović, D., \& Milovanović, B. (2021). Indicators of the wider social context and academic performance of the deaf and hard of hearing students, International Journal of Cognitive Research in Science, Engineering and Education (IJCRSEE), $9(2), 265-274$.

and hard of hearing students, the existence of such organizations means a dignified social life, a place to make friendships to improve communication skills.

It is important to point out that only one specific factor cannot be a risk factor for poor academic achievement of the deaf and hard of hearing students. The correlation of several factors with the academic performance of the deaf and hard of hearing students is confirmed by similar research (Gutman, Sameroff and Cole, 2003; Ellis and Hugues, 2002). Accordingly, it cannot be sufficient to focus on reducing risk by focusing on only one factor. It is very important to recognize the importance of a comprehensive view of academic performance. Furthermore, effective academic failure prevention programmes need to address multiple disruptive factors simultaneously, with an individualized and holistic approach to each student following his or her abilities, capabilities and motivation.

\section{Acknowledgements}

We hereby wish to thank Dr. Jasmina Kovačević, professor of the Faculty for special education and rehabilitation, University of Belgrade, Dr. Olivera Radović, assistant professor at the Faculty of Philosophy, University of Priština, temporarily seated in Kosovska Mitrovica and Zeljko Pokrajac, principal of the elementary school for children with disabilities in the development "Radivoj Popović" in Zemun for their help in the organization and implementation of research.

\section{Conflict of interests}

The authors declare no conflict of interest.

\section{References}

Arroyo, A. A., Rhoad, R., \& Drew, P. (1999). Meeting diverse student needs in urban schools: Research-based recommendations for school personnel. Preventing School Failure: Alternative Education for Children and Youth, 43(4), 145-153. https:// doi.org/10.1080/10459889909604990

Bigler, D., Burke, K., Laureano, N., Alfonso, K., Jacobs, J., \& Bush, M. L. (2019). Assessment and treatment behavioral disorders in children with hearing loss: A systematic review. Otolaryngology - Head and Neck Surgery, 160(1), 36-48. https://doi.org/10.1177/0194599818797598

Blanchett, W. J., Mumford, V., \& Beachum, F. (2005). Urban school failure and disproportionality in a post-brown era: Benign neglect of the constitutional rights of students of color. Remedial and Special Education, 26(2), 70- 81. https://doi.org/ $10.1177 / 07419325050260020201$

Boerrigter, M., Vermeulen, A., Marres, H., Mylanus, E., \& Langereis, M. (2019). Frequencies of behavioral problems reported by parents and teachers of hearing impaired children with cochlear implants. Frontiers in Psychology, 75(10), Article 1591. https://doi.org/10.3389/fpsyg.2019.01591

Cook, W. K., \& Tseng W. (2019). Associations of Asian Ethnicity and Parental Education with Overweight in Asian American Children and Adolescents: An Analysis of 2011-2016 National Health and Nutrition Examination Surveys. Matern Child Health, 23(4), 504-511. https://doi.org/10.1007/s10995-018-2662-3

Chen, X., Liu, H., Chang, L., \& He, Y. (2008). Effects of the Peer Group on the Development of Social Functioning and Academic Achievement: A Longitudinal Study in Chinese Children. Child Development, 79(2), 235-251. https://doi. org/10.1111/j.1467-8624.2007.01123.x

Dimić, N., \& Kljaić, M. (2011). Characteristics of writing with the deaf and hard of hearing children in primary school. In: N. Dimić (ed). Belgrade School for Special Education and Rehabilitation (p p 43-55). Belgrade: Faculty for special education and rehabilitation. Retrieved from https://www.belgradeschool.com/uploads/4/6/5/1/46514917/bds_1_2011_final.pdf

Ellis, D., \& Hughes, K. (2002). Partnerships by Design: Cultivating Effective and Meaningful School-Family-Community Partnerships. Creating Communities of Learning \& Excellence. Retrieved from https://files.eric.ed.gov/fulltext/ ED472442.pdf

Epstein, J. L. (2010). School/family/community partnerships - Caring for the children we share. Phi Delta Kappan, 92(3), 81-96. https://doi.org/10.1177\%2F003172171009200326

Epstein, J. L., Sanders, M. G., Simon, B. S., Salinas, K. C., Jansorn, N. R., ... \& Williams, K. J. (2018). School, family, and community partnerships: Your handbook for action. Corwin Press. Retrieved from https://www.govinfo.gov/content/ pkg/ERIC-ED467082/pdf/ERIC-ED467082.pdf

Fantuzzo, J. E. Tighe, \& Childs, S. (2000). Family involvement questionnaire: a multivariate assessment of family participation in early childhood education. Journal of Educational Psychology, 92(2), 367-376. https://doi.org/10.1037/00220663.92.2.367

Grolnick, W. S. \& M. L. Slowiaczek (1994). Parents' involvement in children's schooling: a multidimensional conceptualization and motivational model. Child Development, 65(1), 237-252. https://doi.org/10.1111/j.1467-8624.1994.tb00747.x.

Grolnick, W. S., C. Benjet, C. O. Kurowski, \& Apostoleris, N. H. (1997). Predictors of parent involvement in children`s schooling, Journal of Educational Psychology, 89(3), 538-548. https://doi.org/10.1037/0022-0663.89.3.538

Guardino, C., \& Antia, S. D. (2012). Modifying the classroom environment to increase engagement and decrease disruption with students who are deaf or hard of hearing. Journal of Deaf Studies and Deaf Education, 17(4), 518-533. https://doi. org/10.1093/deafed/ens026 
Ristić, I., Popović, D., \& Milovanović, B. (2021). Indicators of the wider social context and academic performance of the deaf and hard of hearing students, International Journal of Cognitive Research in Science, Engineering and Education (IJCRSEE), 9(2), 265-274.

Gutman, L. M., Sameroff, A. J., \& Cole, R. (2003). Academic growth curve trajectories from 1stgrade to 12th grade: Effects of multiple social risk factors and preschool child factors. Developmental Psychology, 39, 777-790. https://doi. org/10.1037/0012-1649.39.4.777

Harvey, H., \& Kentish, R. (2010). Factors related to emotional and behavioural difficulties in children with hearing impairment. Educational and Child Psychology, 27(2), 23-32. Retrieved from https://psycnet.apa.org/record/2010-19789-003

Havelka, N. (2000). Student and teacher in the educational process. Belgrade: Institute for Textbooks and Teaching Aids.

Hill, E. N., \& Taylor, L. (2004). Parental School Involvement and Children's Academic Achievement: Pragmatics and Issues. Current Directions in Psychological Science. https://doi.org/10.1111/j.0963-7214.2004.00298.x

Howse, R. (2010). Motivation and Self-Regulation as Predictors of Achievement in Economically Disadvantaged Young Children. The Journal of Experimental Education, 71(2), 151-174. https://doi.org/10.1080/00220970309602061

llić-Stošović, D. (2006). Adoption of the coursework as a criterion for assessment of students with physical disabilities. Special education and rehabilitation 1-2, 151-160. Retrieved from https://scindeks.ceon.rs/article.aspx?artid=1451$32850608151 \mid$

Ivanović, S. (2008). I The ideological role of education. Proceedings of the Faculty of Teacher Education, 10, 9-16.

Jakšić l., \& Malinić D. (2019). Pre-service teachers' perceptions of factors contributing to school failure and their relationship to prior personal experience of school success. Psychology, 52(1), 1-20. https://doi.org/10.2298/psi160211024j

Jevtić, B. (2014). Academic environment and academic (under)achievement. FBIM Transactions https://doi:10.12709/ fbim.02.02.02.16

Jurčević Lozančić A., \& Kunert A. (2015). Parental education and parental pedagogical competence, theoretical and practical challenges. Methodological horizons 10(2), 39-48. https://doi.org/10.32728/mo.10.2.2015.03

Kamal, M., \& Bener, A. (2009). Factors contributing to school failure among school children in very fact developing Arabian Society. Oman Medical Journal, 24(3), 212-217. https://doi.org/10.5001/omj.2009.42

Karić, J., Ristić, S., Medenica, S., Tadić, V., \& Slavnić, S. (2012). Reading characteristics of the deaf and hard of hearing students. Military medical examination, 69(10), 846-851. https://doi.org/10.2298/vsp1210846k

Klarin, M. (2006). Child development in a social context - Parents, peers, teachers - child's development context. Jasterbarsko: Naklada Slap, University of Zagreb.

Kovačević, J. (2007). Educational effects of cooperative learning in the teaching of hearing impaired children, Special education and rehabilitation, Issue 1/2, Special section p18-28. Retrieved from https://web.a.ebscohost.com/abstract?direct=tru e\&profile=ehost\&scope=site\&authtype=crawler\&jrn=14096099\&AN=35968231\&h=RGwTvmRzNVjrJvv0J8DNa6Dwg 2BBs8tbTXOF9t0BHf\%2fiDPRTWAvRsQV\%2bL7jJRpuRUzuYbQBVKToQ4MLiHoWI8w\%3d\%3d\&crl=c\&resultNs=Ad minWebAuth\&resultLocal=ErrCrINotAuth\&crlhashurl=login.aspx\%3fdirect\%3dtrue\%26profile\%3dehost\%26scope\%3d site\%26authtype\%3dcrawler\%26jirnl\%3d14096099\%26AN\%3d35968231

Karchmer, M. A., \& Mitchell, R. E. (2003). Demographic and achievement characteristics of deaf and hard-of-hearing students. In M. Marschark \& P. E. Spencer (Eds.), Oxford handbook of deaf studies, language, and education ( $\mathrm{p} \mathrm{p} 21-37$ ). Oxford University Press. https://doi.org/10.1093/oxfordhb/9780199750986.013.0003

Lenonen, J., T. Solantaus \& Punamaki, P. R. (2003). Social support and the quality of parenting under economic pressure and workload in Finland: the role of family structure and parental gender. Journal of Family Psychology, 17(3), 419-418. https://doi.org/10.1037/0893-3200.17.3.409

Malinić, D. (2009). Failure at school. Belgrade: Institute for Pedagogical Research.

Mailinić, D. (2014). Pedagogical aspects of the teaching profession and student failure. Teaching and education. 63(4), 687701. Retrieved from https://scindeks.ceon.rs/article.aspx?artid=0547-33301404687M

Mijatović S., \& Radovanović V. (2020). Behavioral characteristics of the deaf and hard of hearing and students of typical development in the educational process. Special education and rehabilitation, 19(3), 181-194. https://doi.org/10.5937/ specedreh19-28163

Milovanović, B. L. (2014). Importance of readers for junior classes from an education aims standpoint. Zbornik radova Filozofskog fakulteta u Prištini, (44-2), 268-280. https://doi.org/10.5937/zrffp44-6275

Morison - Gutman, L., Sameroff, A., \& Cole, R. (2003). Academic growth curve trajectories from 1st grade to 12 th grade: effects of multiple social risk factors and preschool child factors, Developmental Psychology, 39(4), 777-790. https:// doi.org/10.1037/0012-1649.39.4.777

Pavković I., Roksandić I. \& Kovačević J. (2018). Family as an indicator of achievement of deaf and hard of hearing students. Human Research in Rehabilitation, 8(1) 4-9. Retrieved from https://human.ba/wp-content/uploads/2018/04/Article-1. pdf

Petersen, L. J. (2010). Parents and educators' perceptions of factors influencing high rate of academic failure of learners in Clarke estate primary schools (Unpublished master thesis). University of the Western Cape, Republic of South Africa. Retrieved from http://hdl.handle.net/11394/1950

Poulou, M. (2014). The effects on students' emotional and behavioural difficulties of teacher-student interactions, students' social skills and classroom context. British Educational Research Journal, 40(6), 986-1004. https://doi.org/10.1002/ berj. 3131

Popović, D. (2019). Family and school in the prevention of peer violence. Novi Pazar: State University of Novi Pazar. Retrieved from http://ceoprora.rs/tekstovi/Porodica_i_skola_u_prevenciji_vrsnjackog_nasilja.pdf

Radovanović, V. \& Karić, J. (2011). Teachers' attitudes towards the application of information and communication technologies in schools for the deaf and hard of hearing students. Special education and rehabilitation, 10(1), 37-48. Retrieved from http://scindeks.ceon.rs/article.aspx?artid=1452-73671101037R

Radoman, V. \& Nikolić, G. (2013). The role of sign language in improving the communication skills and school success of children with hearing impairment. Psychology, 46(1), 77-91. https://doi.org/10.2298/PSI1301077R

Riley, T. \& Ungerleider, C. (2012). Self-fulfilling Prophecy: How Teachers' Attributions, Expectations, and Stereotypes Influence the Learning Opportunities Afforded Aboriginal Students. Canadian Journal of Education, 35(2), 303-333. Retrieved from https://files.eric.ed.gov/fulltext/EJ975282.pdf

Ristic I. (2018). School as an indicator of academic performance of the deaf and hard of hearing students and students of typical development. Specificity of hearing impairment. -steps and leaps. Thematic collection of papers. University of 
Ristić, I., Popović, D., \& Milovanović, B. (2021). Indicators of the wider social context and academic performance of the deaf and hard of hearing students, International Journal of Cognitive Research in Science, Engineering and Education (IJCRSEE), 9(2), 265-274.

Belgrade, Faculty of Special Education and Rehabilitation, Publishers Center, p.199.

Roksandić l. (2014). Results of school success research. Belgrade School for Special Education and Rehabilitation, DDS and the Faculty of Special Education and Rehabilitation, 20(3), 553-562. Retrieved from https://www.belgradeschool.com/ uploads/4/6/5/1/46514917/bds_3_2014_part_i.pdf

Roksandić I. (2016). Indicators of school achievement of deaf and hard of hearing students in primary school success. (Unpublished doctoral dissertation). Belgrade: Faculty for Special Education and Rehabilitation, University of Belgrade. Retrieved from https://uvidok.rcub.bg.ac.rs/bitstream/handle/123456789/1559/Doktorat.pdf?sequence=1\&isAllowed=y

Roksandić I. \& Kovačević J. (2016a). Cooperation between the family and the school in the prevention of school failure of the deaf and hard of hearing students. Specificity of hearing impairment - new steps. Thematic collection of papers. University of Belgrade. Faculty of Special Education and Rehabilitation. Publishing Center (ICF), pp 177179

Roksandić I. \& Kovačević J. (2016b). Behaviour of the deaf and hard of hearing students and school performance. Pedagogija, 71(3), 316-327. Retrieved from http://www.forumpedagoga.rs/wp-content/uploads/2018/06/Pedagogija\%20br.\%20 3\%20za\%202016.pdf

Roksandić I., Pavković I. \& Kovačević J. (2018). The characteristics of behavior of deaf and hard-of-hearing learners in different types of school environment. Human Research in Rehabilitation, Institute for Human Rehabilitation, 8(1), 27-34. Retrieved from https://human.ba/wp-content/uploads/2018/04/Article-3.pdf

Redding, S. \& Walberg, H. J. (2012). Promoting Learning in Rural Schools. Academic Development Institute. Kickapoo Street Lincoln, Illinois: Center on Innovation \& Improvement 121 N. Retrieved from https://www.adi.org/downloads/ Promoting_Learning_in_Rural_Schools.pdf

Reed, S., Shirin D. A. \& Kreimeye K. H. (2008). Academic Status of Deaf and Hard-of-Hearing Students in Public Schools: Student, Home, and Service Facilitators and Detractors. Journal of Deaf Studies and Deaf Education, 13(4), 485-502. https://doi.org/10.1093/deafed/enn006

Seeley, K. (2004). Gifted and talented students at risk. Focus on Exceptional children, 37(4),11-18. https://doi.org/10.17161/ foec.v37i4.6870

Simić-Vukomanović, I., Đukić Dejanović, S., Đonović, N. \& Borovčanin, M. (2012). Psycho-medical and social factors of school success. Engrami, 34(1), 45-47, Retrieved from https://scindeks-clanci.ceon.rs/data/pdf/0351-2665/2012/035126651201045S.pdf

Stamatović, J. D. \& Stojanović, I. D. (2019). The role of school in peer violence prevention. Zbornik radova Pedagoškog fakulteta, Užice, (21), 45-60. Retrieved from https://scindeks.ceon.rs/article.aspx?artid=2560-550X1921045X

Stanojević, D. L. \& Jovanović, A. S. (2018). Teachers' attitudes towards the application of individualization in descriptive assessment of students. Innovations in teaching - Journal of Contemporary Teaching, 31(4), 74-88. Retrieved from https://scindeks.ceon.rs/article.aspx?artid=0352-23341804074S

Stanojlović, B. (2012). Fundamentals of pedagogical diagnostics. Belgrade: Educational review.

Sheridan, S. M., \& Kratochwill, T. R. (2007). Conjoint behavioral consultation: Promoting family-school connections and interventions. Springer Science \& Business Media. https://doi.org/10.1007/978-0-387-71248-2

Swift, D. F. (1975). Social class and achievement motivation; in J. Whitehead (ed.): Personality and learning, (p p 142-158). Hodder and Stoughton. https://doi.org/10.1080/0013188660080202

Taylor, R., Roberts D. \& Jacobson L. (1997). Stressful life events, psychological wellbeing, and parenting in African American mothers L. Journal of Family Psychology, 11(4), 436-446. https://doi.org/10.1037/0893-3200.11.4.436

Vilotijević, M. \& Vilotijević, N. (2014). Vrednovanje kvaliteta rezultata i procesa učenja. Inovacije u nastavi, 27(4), 21-30. https:// doi.org/10.5937/inovacije1404021v

Zins, J. E., Weissberg, R. P., Wang, M. C. \& Walberg, H. J. (2004). Building school succession social and emotional learning: What does the research say? New York: Teachers College Press. Retrieved from https://psycnet.apa.org/ record/2004-21939-000

West, A., \& Pennell, H. (2003). Underachievement in Schools. London: Routledge Falmer. 